Jurnal Kebidanan 08 (02) 127-224

Jurnal Kebidanan

http : /www.journal.stikeseub.ac.id

\title{
POLA ASUH DAN PERKEMBANGAN ANAK USIA 2 -3 TAHUN
}

\author{
Triani Yuliastanti ${ }^{1)}$, Etika Khoiriyah ${ }^{2)}$ \\ ${ }^{1)}$ Prodi D3 Kebidanan STIKES Estu Utomo Boyolali, ${ }^{2)}$ Akademi Kebidanan Anugerah Bintan \\ Tanjung Pinang \\ E-mail:trianieub@gmail.com,Etika2811@gmail.com
}

\begin{abstract}
ABSTRAK
Perilaku sosial (personal sosial) merupakan salah satu kategori perkembangan anak toddler yang berhubungan dengan kemampuan mandiri seperti memakai baju sendiri, pergi ke toilet sendiri, bersosialisasi dan berinteraksi dengan lingkungannya. Perkembangan personal sosial anak toddler tidak semuanya maksimal lebih dari $25 \%$ anak toddler mengalami keterlambatan perkembangan. Keterlambatan perkembangan tersebut dapat dipengaruhi oleh berbagai faktor terutama dari faktor orang tua yaitu pola pengasuhan. Penelitian ini bertujuan untuk mengetahui gambaran pola asuh, gambaran perkembangan personal sosial dan hubungan pola asuh orang tua dengan perkembangan personal sosial anak toddler. Penelitian dilakukan dengan menggunakan metode survey analitik dan pendekatan waktu cross sectional. Populasi dalam penelitian ini adalah semua anak usia 2-3 tahun sejumlah 53, dengan teknik purposive sampling diperoleh sampel 49 dan analisa data chi square. Hasil perhitungan chi square dengan $\alpha=0,05$, diperoleh nilai $X^{2}$ hitung 11.031 dan $\mathrm{p}$ value $=0,004(\mathrm{p}<0,05)$, berarti Ha diterima dan Ho ditolak. Dari penelitian ini dapat disimpulkan bahwa ada hubungan pola asuh orang tua dengan perkembangan personal sosial anak usia 2-3 tahun.
\end{abstract}

Kata Kunci: Pola asuh, Perkembangan personal anak usia $2-3$ tahun.

\section{PARENTING AND CHILD DEVELOPMENT AGE 2-3 YEARS}

\begin{abstract}
Social behavior (personal social) is one category toddler child development associated with the ability to independently like to wear their own clothes, go to the toilet alone, socialize and interact with their environment. Personal social development of children toddler not all up more than $25 \%$ of children experiencing developmental delays toddler. The developmental delay can be influenced by various factors, especially on the factors parents are parenting. This study aims to describe parenting, on the development of social and personal relationships parenting parents with personal social development of children toddler. The study was conducted using analytical survey method and cross sectional approach. The population in this study were all children aged 2-3 years a number 53, by using purposive sampling obtained 49 samples and data analysis chi square. The calculation result of chi square with $\alpha=0.05$, the value of X2 count 11031 and $p$ value $=0.004$ ( $p$ <0.05), means Ha Ho accepted and rejected. From this study we can conclude that there is a relationship with the parents' parenting personal social development of children aged 2-3 years.
\end{abstract}

Keywords: parenting, personal development of children aged 2-3 years.. 


\section{PENDAHULUAN}

Masa balita adalah masa emas (golden age) dalam rentang perkembangan seorang individu, dimana anak mengalami pertumbuhan dan perkembangan yang luar biasa, dan tahapan ini merupakan masa ideal untuk mempelajari berbagai keterampilan (Hurlock, 2005). Berdasarkan laporan Departemen kesehatan Republik Indonesia (2010) cakupan pelayanan kesehatan balita dalam deteksi dini tumbuh kembang balita adalah $78,11 \%$, untuk Provinsi Jawa Tengah 89,33\%. Dengan jumlah balita yang mengalami gangguan tumbuh kembang di Indonesia 45,7\% untuk provinsi Jawa Tengah $32,6 \%$. Sedangkan berdasarkan laporan dari Ketua Yayasan Anak Autis Indonesia juga menunjukkan adanya peningkatan jumlah anak autis pada tahun 2000 1: 5000 anak dan pada tahun 2010 menjadi 1:500 anak (Suherman, 2010).

Pola asuh dapat diartikan sebagai suatu cara perlakuan orang tua yang diterapkan pada anak. Pola asuh anak telah dikelompokkan dalam 3 tipe, yaitu: bisa demokratis, otoriter, dan permisif. Anak yang berusia 1-3 tahun disebut dengan Toddler, dimana anak mengalami lompatan kemajuan yang menakjubkan, tidak hanya kemajuan secara fisik tetapi juga secara sosial dan emosional, anak mulai mengenal dunia secara lebih mendalam dan menyerap apa saja yang ada disekitarnya. Tumbuh kembang anak toddler mempunyai dampak yang cukup besar terhadap kualitas dimasa dewasa karena periode ini paling penting dan rawan bagi keberhasilan tumbuh kembang anak (Hurlock, 2005).

Berdasarkan hasil sensus penduduk tahun 2010 jumlah anak usia 0-4 tahun 23.512.851 jiwa. Sedangkan usia 0-4 tahun di Jawa Tengah 2.711.271. Maka dari itu perkembangan anak sangat perlu untuk diperhatikan. Serta jumlah balita usia 0-4 tahun di Kabupaten Klaten 88.923 jiwa, dimana 21,5\% mengalami keterlambatan tumbuh kembang (DepKes RI, 2010).

Perkembangan anak toddler ditandai dengan peningkatan kemandirian yang diperkuat dengan kemampuan mobilitas fisik dan kognitif yang lebih besar. Perkembangan ketrampilan motorik, kognitif dan sosial yang cepat membolehkan anak untuk berpartisipasi dalam tindakan perawatan diri sendiri seperti makan, berpakaian dan eliminasi. Seiring dengan peningkatan kemampuan, anak toddler memiliki ciri-ciri selalu ingin mencoba apa yang bisa dilakukan, menuntut dan menolak apa yang ia mau atau yang mereka tidak mau, dan tertanam perasaan otonomi (DepKes RI, 2010).

Perilaku sosial (personal sosial) adalah aspek yang berhubungan dengan 
kemampuan mandiri seperti memakai baju sendiri, pergi ke toilet sendiri, bersosialisasi dan berinteraksi dengan lingkungannya. Sedangkan menurut DepKes RI dalam buku pedoman stimulasi, deteksi dan intervensi dini tumbuh kembang anak (2005) menyatakan bahwa perkembangan sosial anak adalah proses perubahan yang berlangsung secara terus menerus menuju kedewasaan yang memerlukan adanya komunikasi dengan masyarakat, lebih dari $25 \%$ anak toddler mengalami keterlambatan perkembangan seperti kurangnya kemandirian anak (tidak dapat berpakaian sendiri, tidak berhasil dalam toilet training), tidak bisa berkomunikai dengan lancar dimana anak tidak mampu menyebutkan namanya sendiri sehingga anak cenderung pasif dan tidak dapat mengembangkan kemampuannya. Salah satu hal yang menghambat kemandirian anak adalah kebiasaan anak yang masih sangat tergantung pada orang tua hal ini ditunjukkan dengan orang tua yang menunggui anaknya belajar di PAUD secara penuh (Suherman, 2010).

Dalam perkembangan anak semua aspek yang dimiliki orang tua berpengaruh besar terhadap perkembangan dimana sosial ekonomi orang tua mempengaruhi perkembangan anak $20,4 \%$, pekerjaan orang tua $23,3 \%$, dan pola asuh orang tua $36,7 \%$, dan sisanya besar dipengaruhi faktor lingkungan. Orang tua merupakan tokoh sentral dalam perkembangan anak terutama dalam pola pengasuhan anak sikap positif sangat diperlukan dalam membimbing tumbuh kembang anak agar sesuai tahapan perkembangan anak, jadi dari dasar ini dapat diteladani bahwa peran orang tua dalam pola pengasuhan sangat bisa menentukan aktifitas sosial anak seperti kemandirian, membantu kegiatan dirumah dan lingkungan sekitar. Apabila anak mampu melakukan penyesuaian sosial dengan baik, anak akan mudah diterima sebagai anggota kelompok sosial ditempat mereka mengembangkan diri. (Suherman, 2010).

Pola Asuh Pola asuh adalah merupakan pola interaksi antara orang tua dan anak dimana bagaimana sikap atau perilaku orang tua saat berinteraksi dengan anak termasuk caranya menerapkan aturan, mengajarkan nilai/norma, memberikan perhatian dan kasih sayang serta menunjukkan sikap dan perilaku yang baik sehingga dijadikan contoh atau panutan bagi anaknya (Shanti, 2008).

Syarat Pola Asuh Menurut Shanti (2008) bagaimana bentuk pola asuh agar pola asuh menjadi efektif antara lain: Pola asuh harus dinamis karena pola asuh harus sejalan dengan meningkatnya pertumbuhan dan perkembangan anak, contoh pola asuh batita berbeda dengan pola asuh anak usia sekolah. Pola asuh 
sesuai dengan kebutuhan dan kemampuan anak ini perlu dilakukan karena setiap anak memiliki minat dan bakat berbeda. Bakat anak mulai terlihat ketika anak usia satu tahun, potensi anak sudah mulai terlihat, umpamanya bila sikecil mendengarkan musik dia tampak tertarik ketimbang anak seusianya, bisa jadi ia memiliki potensi kecerdasan musikal.

Pola asuh disertai perilaku positif orang tua. Penerapan pola asuh juga membutuhkan sikap-sikap positif dari orang tua sehingga bisa dijadikan contoh atau panutan bagi anaknya. Komunikasi efektif merupakan sub bagian dari pola asuh efektif. Syaratnya sederhana meluangkan waktu untuk berbincangbincang dengan anak, jadilah pendengar dan tidak meremehkan pendapat anak.

Penerapan disiplin juga menjadi bagian pola asuh. Namun penerapan disiplin mesti fleksibel disesuaikan dengan kebutuhan dan kondisi anak misalnya dalam kondisi kelelahan. Orang tua harus konsisten jangan sampai lain kata dengan lain perbuatan misal saat orang tua batuk pilek malah minum air dingin.

Tipe pola asuh orang tua, pola pengasuhan menurut Tracy Hogg (2004) dibagi menjadi 3 jenis, yaitu: Otoriter adalah pola pengasuhan anak yang bersifat keras dan kaku di mana orangtua akan membuat berbagai aturan yang harus dipatuhi oleh anak-anaknya, dimana orang tua jarang berkomunikasi dengan anak tidak mau mendengarkan pendapat anaknya. Permisif adalah jenis pola mengasuh anak yang tidak peduli terhadap anak. Dalam pola asuh ini orang tua sangat jarang berkomunikasi verbal pada anaknya. Anak bebas menyampaikan keinginan tanpa batasan. Demokratis (Memberikan Pilihan) orang tua yang bisa diandalkan menyeimbangkan kasih sayang dan dukungan emosional dengan struktur dan bimbingan dalam membesarkan anakanak mereka.

Perkembangan Personal Sosial

Perkembangan (Development) adalah bertambahnya kemampuan (skill) dalam struktur dan fungsi tubuh yang lebih kompleks dalam pola yang teratur sebagai hasil dari proses pematangan. Di sini menyangkut adanya proses diferensasi sel-sel tubuh, jaringan tubuh, organ, dan sistem organ yang berkembang sedemikian rupa sehingga masing-masing dapat memenuhi fungsinya. Termasuk perkembangan emosi, intelektual, dan tingkah laku sebagai hasil interaksi dengan lingkungan (Soetjiningsih, 2007). Perkembangan personal sosial (kepribadian/ tngkah laku adalah) adalah berhubungan dengan kemandirian, bersosalisasi dan berinteraksi dengan lingkungan (Soetjiningsih, 2007). 
Prinsip-prinsip perkembangan personal sosial : Perkembangan bertujuan untuk pencapaian realisasi diri atau pencapaian kemampuan bawaan. Perkembangan awal yang sangat mempengaruhi proses belajar dan pengalaman lebih penting dari pada perkembangan selanjutnya. Sehingga perkembangan awal merupakan dasar dari perkembangan selanjutnya. Perkembangan timbul karena adanya interaksi antara kematangan dengan proses belajar. Pola perkembangan mempunyai karakteristik tertentu yaitu dapat diperlambat atau dipercepat oleh kondisi lingkungan dimasa pralahir dan pasca lahir. Dalam semua periode perkembangan terdapat saat keseimbangan dan keseimbangan. Periode-periode tersebut antara lain: periode pralahir, masa neonatus, masa bayi, masa kanak-kanak awal, masa kanak- kanak akhir, dan masa puber. Adanya harapan sosial untuk setiap periode perkembangan yang memungkinkan orang tua yang mengetahui usia anak mampu menguasai berbagai pola perilaku yang diperlukan bagi penyesuaian yang baik. Setiap bidang perkembangan mengandung kemungkinan bahaya baik fisik maupun psikologis yang dapat mengubah pola perkembangan. Kebahagiaan bervariasi pada berbagai periode dalam pola perkembangan. Tahun pertama kehidupan biasanya yang paling bahagia dan masa puber biasanya yang paling tidak bahagia (Hurlock,2005)

Aspek perkembangan personal Sosial adalah : Kemampuan mandiri anak dapat dilihat dari kemampuan anak dalam memenuhi kebutuhannya sendiri dalam kehidupan sehari-hari. Sesuai dengan Soetjiningsih (2005) aspek kemandirian anak meliputi menatap muka, berusaha mencapai aminan, makan sendiri,minum dari cangkir, menggunakan sendok garpu, membuka pakaian, memakai baju, gosok gigi, membantu dirumh, cuci dan mengetingkan tangan, memakai $\mathrm{t}$ shirt, mengambil makan. Kemampuan anak dalam bersosialisasi adalah aspek penting dalam perkembangan personal sosial anak. Kemampuan anak yang mudah bersosialisasi akan memudahkan anak untuk bergaul dimasyarakat. Sesuai dengan Soetjiningsih (2005) aspek tersebut meliputi tersenyum spontan, mengamati tangan, tepuk tangan, main bola dengan pemeriksa, menitukan kegiatan, menyebut nama teman, bermain ular tangga kartu. Seorang anak seharusnya mampu berinteraksi dengan baik terhadap lingkungannya, sehingga dapat diterima dengan baik dimasyarakat (Tracy, 2004). Sesuai dengan Soejiningsih (2005) aspek tersebut meliputi membahas senyum pemeriksa, menyatakan keinginan, da-da dengan tangan, menyuapi boneka. 
Faktor-faktor mempengaruhi perkembangan menurut Lawrence Green dalam buku Perilaku Kesehatan tahun 2010, perilaku kesehatan seseorang atau masyarakat dipengaruhi oleh 2 faktor pokok, yakni faktor perilaku (behavior causes) dan faktor di luar perilaku (nonbehaviour causes). Selanjutnya perilaku itu sendiri ditentukan atau terbentuk dari 3 faktor, yaitu: Faktor-faktor predisposisi (predisposing factors), faktor-faktor pendukung (Enabling factors), faktorfaktor pendorong (Renforcing factors)

Alat Ukur Perkembangan yang dipakai untuk mengetahui perkembangan anak, dalam hal ini alat ukur atau tes perkembangan yang digunakan adalah Denver II. Denver II adalah revisi utama dan standarisasi umum dari Denver Developmental Screening Test (DDST) dan Revised Denver Developmental Screening Test (DDST-R). Tes ini dibuat oleh Frankenburg dan J.B. Dodds. Denver II berbeda dari tes skrining sebelumnya dalam bagianbagian yang meliputi : bentuk, interpretasi, dan rujukan (Wong, 2005).

\section{METODE}

Penelitian ini dilakukan dengan menggunakan metode survey analitik dan pendekatan waktu cross sectional. Metode penelitian survey analitik yaitu penelitian untuk mengetahui hubungan variabel bebas dan variabel terikat melalui observasi langsung terhadap subyek penelitian. (Notoatmodjo, 2010). Dengan rancangan kegiatan pada penelitian adalah sebagai berikut, populasi dalam penelitian ini adalah semua anak usia 2-3 tahun di PAUD Tetuko Desa Kios Kebondalem Lor Prambanan Klaten sejumlah 53 dimana semua anak tersebut merupakan anak toddler. Sedangkan sampel dari populasi yang ada adalah anak usia 2-3 tahun di PAUD Tetuko Desa Kios Kebondalem Lor Prambanan Klaten, dimana anak tersebut merupakan anak toddler yaitu sejumlah 49 responden.

Sampel dalam penelitian ini akan diambil secara purposive sampling yaitu teknik pengambilan sampel dengan pertimbangan tertentu yang dibuat oleh peneliti sendiri, berdasarkan cirri atau sifat-sifat populasi yang sudah diketahui sebelumnya (Notoatmodjo, 2010). Pengambilan sampel menggunakan criteria inklusi dan ekslusi. Analisis yang digunakan untuk mengetahui hubungan dua variabel atau lebih (Sugiyono. 2010). Pengujian statistik chi square $\left(X^{2}\right)$. Harga Chi Square di cari dengan rumus (Arikunto, 2010). Sedangkan definisi operasional dari penelitian ini adalah :

Pola Asuh Orang tua yaitu Perilaku yang dipraktekkan oang tua (bapak dan ibu) dalam memberikan pemeliharaan kesehatan, memberikan stimulasi, serta dukungan emosional 
yang dibutuhkan anak untuk pertumbuhan dan perkembangan. Alat ukur kuesioner, skala data pola asuh orang tua Nominal. Hasil ukur Oteriter (bila orang tua lebih banyak menjawab Ya soal nomor 1-7), Permisif (bila orang tua lebih banyak menjawab Ya soal nomor 8-14), Demokratis (bila orang tua lebih banyak menjawab Ya soal nomor 15-21. Perkembangan personal sosial anak usia $2-3$ tahun adalah kemampuan anak yang berhubungan dengan aspek kemampuan mandiri, bersosialisasi dan berinteraksi dengan lingkungannya. Alat ukur perkembangan personal sosial adalah Lembar observasi menurut Denver II dengan kriteria jawaban ya skor 1 dan tidak skor 0 , skala data perkembangan personal sosial ordinal. Hasil ukur: Normal apabila tidak ada keterlambatan, Tidak normal terdapat satu atau lebih keterlambatan.

\section{HASIL DAN PEMBAHASAN}

Tabel 1. Pola Asuh Dan Perkembangan Anak Usia 2 -3 Tahun

\begin{tabular}{ccccccccc}
\hline \multirow{2}{*}{ Pola asuh } & \multicolumn{9}{c}{ Perkembangan Personal Sosial anak Toddler } & \multirow{2}{*}{$\mathrm{X}^{2}$} & \multirow{2}{*}{ P value } \\
\cline { 2 - 6 } & \multicolumn{2}{c}{ Normal } & \multicolumn{2}{c}{ Tidak } & \multicolumn{2}{c}{ Total } & & \\
\cline { 2 - 7 } & $\mathrm{f}$ & $\%$ & $\mathrm{f}$ & $\%$ & $\mathrm{~F}$ & $\%$ & & \\
\hline Demoratis & 16 & 32.7 & 7 & 14.3 & 23 & 46.9 & & \\
Otoriter & 2 & 4.1 & 10 & 20.4 & 12 & 24.5 & \multirow{2}{*}{03.031} & 0,004 \\
Permisif & 4 & 8.2 & 10 & 20.4 & 14 & 28.6 & & \\
\hline Total & 22 & 44.9 & 27 & 55.1 & 49 & 100 & & \\
\hline
\end{tabular}

Sumber :Data Primer

Hasil penelitian menunjukkan bahwa pola asuh otoriter akan menghasilkan karakteristik anak yang tidak bahagia, paranoid (selalu berada dalam ketakutan), mudah sedih dan tertekan, pendiam, tertutup, tidak berinisiatif, menentang, suka melanggar norma, berkepribadian lemah, cemas dan menarik diri. Namun di balik itu biasanya anak hasil didikan orang tua otoriter lebih bisa mandiri, bisa menjadi orang sesuai keinginan orang tua, lebih disiplin dan lebih bertanggungjawab dalam menjalani hidup (Hurlock, 2005). Pada pola pengasuhan permisif anak cenderung hanya diberi materi atau harta saja dan terserah anak itu mau tumbuh dan berkembang seperti apa. Pola Asuh ini akan menghasilkan anak yang kurang perhatian, merasa tidak berarti, rendah diri, nakal, memiliki kemampuan bersosialisasi yang buruk, kontrol diri yang buruk, salah bergaul, kurang menghargai orang lain, manja, kurang mandiri, kurang percaya diri, dan kurang matang secara sosial baik ketika masih kecil maupun sudah dewasa (Soejiningsih, 2005). Salah satu factor tidaklah mutlak bahwa perkembangan personal sosial anak toddler 
dipengaruhi oleh pola asuh, masih banyak faktor lain yang mempengaruhi perkembangan personal sosial anak toddler yang utama adalah lingkungan nutrisi dan stimulasi pada anak tersebut. Kemampuan orang tua dalam memberikan stimulasi pada anak sangat tergantung pada pendidikan orang tua tersebut menurut Nursalam (2011) bahwa semakin tinggi tingkat pendidikan seseorang maka diharapkan semakin baik tingkat pengetahuannya, sedangkan menurut Dictionary of Education, mengatakan bahwa pendidikan dapat diartikan suatu proses dimana seseorang menggembangkan kemampuan sikap dan bentuk tingkah laku lainnya dalam masyarakat dan kebudayaan.

Hal ini sesuai dengan penelitian Eka Hastuti (2011) yang mengatakan bahwa tingkat pendidikan mempengaruhi pengetahuan ibu tentang pemberian stimulasi pada balita. Beberapa hasil penelitian juga menunjukkan bahwa dengan pola asuh otoriter anak cenderung memiliki perkembangan yang normal. Hal ini dapat dikarenakan oleh faktor keluarga dan genetik.

\section{PENUTUP}

Berdasarkan uraian diatas dapat disimpulkan bahwa terdapat hubungan antara antara pola asuh orang tua dengan perkembangan personal sosial anak toddler. Dimana pola asuh demokratis akan membuat perkembangan anak lebih baik dan sesuai dengan kurva perkembangan yang diharapkan. Pola Asuh Orang tua Perilaku yang dipraktekkan oang tua (bapak dan ibu) dalam memberikan pemeliharaan kesehatan, memberikan stimulasi, serta dukungan emosional yang dibutuhkan anak untuk pertumbuhan dan perkembangan. Perkembangan personal sosial anak kemampuan anak yang berhubungan dengan aspek kemampuan mandiri, bersosialisasi dan berinteraksi dengan lingkungannya. Saran yang dapat disampaikan dari hasil penelitian ini adalah diupayakan sejak dini orangtua lebih condong dalam pola asuh demokratis sehingga anak-anak akan bisa belajar lebih awal untuk bersikap toleransi, menghargai pendapat orang lain dan berani mengambil keputusan.

\section{DAFTAR PUSTAKA}

Anoraga. 2006. Membangun Anak Berprestasi. Diakses tanggal: 1 April 2013 from: http.//www.intisarioinline.com.

Arikunto, Suharsimi, 2010. Prosedur Penelitian Suatu Pendekatan Praktek. Jakarta: Rineka Cipta. Hal : 174, 213,223

DepKes RI. 2010. Buku pedoman Stimulasi Deteksi dan Intervensi Dini Tumbuh Kembang Anak. Jakarta: DepKes RI. Hal : 56 
DepKes RI. 2010. Profil Kesehatan Indonesia 2010. Diakses pada tanggal 30 Maret 2013. From: http://www.depkes.go.id

Drew.2006. Perkembangan Anak, Diakses tanggal: 1 April 2013 from:

http:www.prevention/psu.edu/e vent.

Dewi dan Wawan. 2011. Pengetahuan, Sikap, dan Perilaku Manusia. Yogyakarta: Nuha Medika. Hal : 15

Hurlock, EB. 2005.Perkembangan Anak, Jilid I. Jakarta : Erlangga. Hal : 149, ,225

Notoatmodjo, Soekidjo. 2010. Ilmu Perilaku Kesehtan. Jakarta : Rineka Cipta. Hal : 34, 49 2007. Promosi Kesehatan Dan Ilmu Perilaku. Jakarta : Rineka Cipta. Hal : 180 Metodologi Penelitian Kesehatan. Jakarta : Rineka Cipta. Hal : 96,110

Riwikdikdo, Handoko. 2010. Statistik Untuk Penelitian Kesehatan Dengan Aplikasi

Program R dan SPSS. Yogyakarta: Pustaka Rihama. Hal : 174, 213,223

Shanti. 2008. Pola Asuh Anak. Diakses tanggal: 1 April 2013 from: www.TanyaDokter.com

Soetjiningsih. 2007. Tumbuh Kembang Anak, Penerbit Buku Kedokteran. Jakarta:EGC. Hal : 76,83,96

Sugiyono. 2010. Statistika Untuk Penelitian. Bandung: alfabeta. Hal : 174, 213,223

Suherman. 2007. Perkembangan Anak Toddler. Diakses tanggal: 3 April 2013 from: www.InfoIbu.com.
Surya.2003. Perkembangan anak. Diakses tanggal: 1 April 2013 from: www.AyahBUnda.com

Tracy Hogg. 2004. Mendidik dan mengasuh anak balita anda. Jakarta: Gramedia pustaka. Hal : 157

Wong. 2005. Buku Ajar Keperawatan Pediatrik.Jakarta: EGC. Hal : 227 